\title{
Bavaria seeks opt-out from university funding system
}

Munich. The Land (state) of Bavaria has said that it wants to opt out of Germany's communal funding system for supporting university infrastructure because the federal government in Bonn does not want to contribute more to the fund than it did last year.

In principle, the Bonn government's decision prevents Bavaria from implementing its full university building programme, even though, as a relatively rich state, it can afford to do so.

Bavaria's declaration has raised a question mark over the future of a 25-year-old law that splits the costs of financing the construction, maintenance and expansion of university buildings - as well as the purchase of major items of university research equipment - equally between the federal government and the host Land.

In general, higher education is the responsibility of Germany's 16 Länder. But the 1970 law was designed to promote common standards by ensuring that buildings in poorer Länder would not become run-down through a lack of money. Building and equipping proposals put forward by the Länder are considered by the Wissenschaftsrat, Germany's science council.

Normally the council's recommendations on financing levels are accepted by all sides. This year, however, general budgetary pressures meant that the federal government agreed to pay only DM1.8 million (US\$1.15 million) for 1995, even though the Wissenschaftsrat had said that Bonn should contribute at least DM2.3 million (see $\mathrm{Na}$ ture 371, 371; 1994).

The Wissenschaftsrat expressed concern that this capping of funds would prevent universities from making any new plans in the next few years. Bavaria, which by law should only match its share of the federal funds, has now indicated that it does not wish to be constrained by the financial problems of the federal government, nor concerned by those of other Länder.

Bavaria is one of Germany's richest Länder and is keen to become the country's science capital (see Nature 371, 189; 1994). Faced with rapidly increasing student numbers, it has embarked on a major university building programme to help relieve overcrowded classrooms.

The Land has already been successful in attracting private finances for some university building projects, including a centre for applied solid-state physics in Augsburg, and a new building for the faculty of applied science in Bayreuth. But Bavaria's prime minister, Edmund Stoiber, wants the government either to increase public funding for universities or to release the Land from the current joint-funding agreement.

Last month, Stoiber announced that Bavaria would continue with its full building programme, as approved by the Wissenschaftsrat. He said that the Land will pay the full costs, and then fight retrospectively in the courts for the federal share, to which he claims it is entitled.

If it loses the battle in the courts, said Stoiber, Bavaria will start negotiations to pull out of the agreement altogether, and fund all university building itself. But in such circumstances, it would expect the federal government to direct a higher share of taxes to Bavaria in other forms.

Alison Abbott

\section{Cambridge turns to its gospels}

London. The sixth-century Canterbury
Gospels (see right) is one of the
highlights of an eclectic mixture of
books, photos, instruments and memora-
bilia that went on show at Christies
auction rooms in London last week. The
exhibits are owned by the University of
Cambridge and are intended to demon-
strate the intellectual contribution made
by the university since it was founded
more than 700 years ago.
The exhibition is part of the Cam-
paign for Cambridge, a 10-year fund-
raising drive, launched five years ago.
But none of the exhibits is for sale and
admission is free; university officials
hope that publicity generated by the
display, opened last week by Princess
Margaret, will give a new boost to fund-
raising efforts.

London. The sixth-century Canterbury Gospels (see right) is one of the books, photos, instruments and memorabilia that went on show at Christies exhibits are owned by the University of Cambridge and are intended to demonstrate the intellectual contribution made by the university since it was founded ore than 700 years ago. raising drive, launched five years ago. But none of the exhibits is for sale and Margaret, will give a new boost to fund-

\section{Russian academy backs off take-over of applied research labs}

Moscow. Leaders of the Russian Academy of Sciences (RAS) have withdrawn their support for plans to create a new organization, the Russian Science and Technology Academy (RSTA), which would have taken over responsibility for all publicly funded applied science.

The plans were announced last autumn (see Nature 372; 208; 1994), and would have given the RSTA control over research institutes, factories and scientific organizations that are now under the jurisdiction of the State Committee of Defence Industries, the Ministry of Atomic Energy and other ministries involved in research and development.

One goal of the proposed move was to save Russia's military research and development complex from collapse. But at a recent meeting of the academy's presidium, it became clear that the 'superacademy' had more opponents than supporters.

The reasons behind the presidium's climbdown on the issue remain unclear. One factor may have been the resignation of Oleg Soskovyets, the first Vice-Premier of Russia, who issued the official order setting up the academy last year.

But the meeting was also told by Igor Lebedyev that scientists in Siberia were strongly opposed to the creation of the RSTA, which many regard as potentially increasing bureaucratic controls, while Gorimir Chyorny questioned whether an academy is the best type of organization to manage applied research institutes. Another academician, Alexander Yanshin, told the meeting that he opposed the creation of any form of state-run academy.

Boris Saltykov, the Russian science minister, has already expressed his opposition to the creation of the RSTA, especially if this were to involve the transfer of control of public institutes. Saltykov's views were endorsed at the academy meeting by Andrei Gonchar, the RAS vice-president.

Indeed, several applied research institutes have themselves opposed the plans. For example, Fyodor Reshetnikov, the director of the Institute of Organic Chemistry (part of the Ministry of Atomic Energy), has questioned assurances by another academy vice-president, Evgeny Velikhov, that institutes would not be forced to join the RSTA. He claims that his institute was included in the plans without his consent.

The RAS's decision to withdraw its support for the RSTA does not necessarily mean that the project will be abandoned. But the continued opposition of the minister of science, combined with the RAS's aboutturn, makes its realization increasingly unlikely.

Vladimir Pokrovsky 